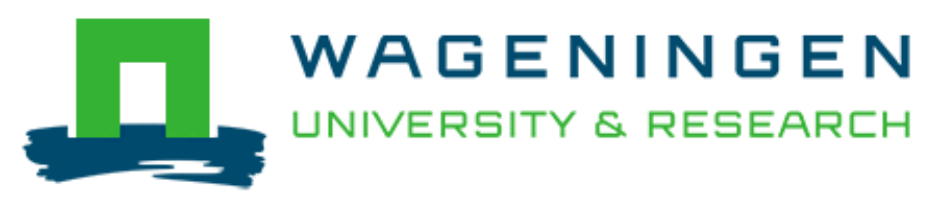

Short-term root and leaf decomposition of two dominant plant species in a Siberian tundra

\author{
Wang, P., van Ruijven, J., Heijmans, M. M. P. D., Berendse, F., Maksimov, \\ A., Maximov, T. C., \& Mommer, L.
}

This is a "Post-Print" accepted manuscript, which has been published in "Pedobiologia"

This version is distributed under a non-commercial no derivatives Creative Commons (c) (1) $(9)$ reproduction in any medium, provided the original work is properly cited and not used for commercial purposes. Further, the restriction applies that if you remix, transform, or build upon the material, you may not distribute the modified material.

Please cite this publication as follows:

Wang, P., van Ruijven, J., Heijmans, M. M. P. D., Berendse, F., Maksimov, A., Maximov, T. C., \& Mommer, L. (2017). Short-term root and leaf decomposition of two dominant plant species in a Siberian tundra. Pedobiologia. DOI:

10.1016/j. pedobi.2017.08.002

You can download the published version at:

https://doi.org/10.1016/j.pedobi.2017.08.002 


\section{Short-term root and leaf decomposition of two dominant plant species in a}

\section{Siberian tundra}

3 Peng Wang ${ }^{\mathrm{a}, \mathrm{b}, *}$, Jasper van Ruijven ${ }^{\mathrm{a}}$, Monique MPD Heijmans ${ }^{\mathrm{a}}$, Frank Berendse ${ }^{\mathrm{a}}$, Ayal Maksimov ${ }^{\mathrm{c}}$,

4 Trofim Maximov ${ }^{\mathrm{c}, \mathrm{d}}$, Liesje Mommer $^{\mathrm{a}}$

5

6 a Plant Ecology and Nature Conservation Group, Wageningen University, PO Box 47, 6700 AA

$7 \quad$ Wageningen, The Netherlands

$8 \quad{ }^{\mathrm{b}}$ College of Resources and Environmental Sciences, Nanjing Agricultural University, 6 Tongwei

9 Road, 210095 Nanjing, China

$10{ }^{\mathrm{c}}$ Institute for Biological Problems of the Cryolithozone, Siberian Branch Russian Academy of

11 Sciences, 41 Lenin Avenue, 677980 Yakutsk, Russia

12

${ }^{\mathrm{d}}$ North-Eastern Federal University, 677000 Yakutsk, Russia

* Corresponding author. E-mail address: pengwangcssc@foxmail.com 


\section{Abstract}

In tundra ecosystems, global warming is expected to accelerate litter decomposition and to lead to shifts in vegetation composition. To understand these shifts, it is important to understand the interactions between global warming, vegetation composition, litter quality and decomposition in the tundra. In addition, it is important to consider root litter since roots are the major part of plant biomass in the tundra. In order to increase our understanding of decomposition, and root decomposition in particular, we performed a litter transplant experiment in northeastern Siberia, in which we measured mass loss for leaf and root litter (live and dead material) of the two dominant plant species, graminoid Eriophorum vaginatum and shrub Betula nana, in three vegetation types (E. vaginatum or B. nana dominated and mixed vegetation) during the growing season.

Our results show that although leaf decomposition did not differ between the two species, root decomposition showed significant differences. Mass loss of live roots was higher for E. vaginatum than for B. nana, but mass loss of E. vaginatum dead roots was lowest. In addition, we found evidence for home-field advantage in litter decomposition: litter of a plant decomposed faster in vegetation where it was dominant. Mass loss rates of the litter types were significantly correlated with phosphorus content, rather than nitrogen content. This indicates that phosphorus limits decomposition in this tundra site.

The low decomposition rate of $B$. nana live roots compared to E. vaginatum live roots suggests that the acceleration of decomposition in the Arctic may be partly counteracted by the expected expansion of shrubs. However, more information on litter input rates and direct effects of climate change on decomposition rates are needed to accurately predict the effects of climate change on carbon dynamics in tundra ecosystems.

Keywords: Arctic tundra, mass loss, Betula nana, Eriophorum vaginatum, home-field advantage, leaf litter, root litter 


\section{Introduction}

Arctic soils are an important global carbon reservoir, as half of the terrestrial belowground organic carbon pool is sequestered in the northern circumpolar soil (Tarnocai et al., 2009). One of the key processes in the global carbon cycle is the decomposition of organic plant litter (Bonan et al., 2013; Wieder et al., 2013). It has been estimated that decomposition of plant litter accounts for half of the terrestrial carbon release into the atmosphere (Houghton, 2007). Therefore, changes in decomposition rates will greatly affect the soil carbon stocks of the Arctic ecosystems.

Important abiotic factors controlling decomposition rates include soil moisture, temperature and nutrient availability (Swift et al., 1979). In the Arctic, temperature arguably is the most important driver of decomposition (Hobbie, 1996; Robinson, 2002), as the soil is frozen for most of the year, strongly limiting decomposition of plant litter. However, due to climate change, temperature has already increased by about $1^{\circ} \mathrm{C}$ in the last century and is predicted to further increase by $2-8^{\circ} \mathrm{C}$ this century (IPCC, 2013; Jones et al., 2012). Consequently, Arctic tundra soils will be warmer, permafrost will thaw and decomposition of organic carbon will be accelerated (Cornelissen et al., 2007; Davidson and Janssens, 2006; Schuur et al., 2009). Ultimately, the Arctic tundra may shift from a net carbon sink to a net carbon source (Belshe et al., 2013; Webb et al., 2016).

In addition to abiotic factors, litter quality is an important driver of decomposition (Cornwell et al., 2008). In general, plant litter with high nutrients and low lignin content decays faster than litter with low nutrients and high lignin content (Freschet et al., 2012; Zhang et al., 2008). In most studies, nitrogen appears to be the most important nutrient limiting decomposition, but phosphorus content has also been found to be related to decomposition (Cornwell et al., 2008; Enriquez et al., 1993). Litter decomposition can differ substantially between plant species or plant functional types (PFTs) within the same ecosystem. In the tundra, the main PFTs are dwarf shrubs and graminoids. Generally, it is thought that shrub litter is less decomposable than graminoid litter, as the former has a higher lignin concentration (Cornelissen et al., 2007; Hobbie, 1996; Zhang et al., 2008).

Decomposition rates may also differ between different plant tissues of the same species. For example, root litter generally decays slower than leaf litter (Birouste et al., 2011; Bryant et al., 1998; 
Fujii and Takeda, 2010; Ma et al., 2016; Robinson et al., 1997; Thormann et al., 2001). In Arctic tundra, up to $70 \%$ of plant biomass is allocated belowground (Iversen et al., 2015; Poorter et al., 2012; Wang et al., 2016a). This high fraction suggests that root litter is a major source of carbon input and root litter decomposition is likely to be an important component of the carbon cycle in this ecosystem. However, detailed information about differences in root litter decomposition rates among species or PFTs in the field is scarce. Hobbie (1996) and Robinson et al. (1999) showed that root and/or leaf litters of graminoid species decomposed faster than those of shrub species, but these experiments were performed under controlled conditions.

Understanding the differences in decomposition rates between PFTs is particularly relevant in the Arctic as both recent observations and experimental researches show that climate warming affects the distribution and abundance of the different PFTs (Elmendorf et al., 2012; Hill and Henry, 2011; Tape et al., 2006). Shrub expansion has been observed in many tundra ecosystems (Callaghan et al., 2011; Myers-Smith et al., 2011a; Myers-Smith et al., 2011b; Tape et al., 2006; Wookey et al., 2009). Such changes in plant distribution and abundance will likely lead to differences in the quantity and quality of litter input into the soil, which may affect decomposition rates and thus carbon cycling (Aerts, 2006; Berendse et al., 1989; Berendse et al., 1987; Cornelissen et al., 2007).

Moreover, there are feedbacks among vegetation type and decomposition rates (Ward et al., 2015). Decomposition of plant litter can be up to $70 \%$ faster in the species' own habitat compared to a different environment, a phenomenon referred to as "home-field advantage" (Gholz et al., 2000; Strickland et al., 2009; Veen et al., 2015a). Home-field advantage effects on decomposition have been observed worldwide (Ayres et al., 2009; Veen et al., 2015a), but have rarely been studied in tundra ecosystems. One study we know determined home-field advantage in a sub-arctic tundra ecosystem but found no support for it (Veen et al., 2015b).

Here, we determined the decomposition rates of leaf and root litter for the two dominant species, representing the main PFTs in Siberian tundra, and tested for home-field advantage effects. We performed a litter transplant experiment, in which leaf and root litters of both the graminoid 
Eriophorum vaginatum L. and the deciduous shrub Betula nana $\mathrm{L}$. were incubated for five weeks during the growing season in three different vegetation types: E. vaginatum-dominated, B. nanadominated, and mixed vegetation. We hypothesized that:

1. The decomposition rate of root litter is lower than that of leaves,

2. The decomposition rate of E. vaginatum litter is lower than that of B. nana,

3. Differences in decomposition rates between litter types and species are related to litter quality,

4. Litter of a species decomposes faster in its own vegetation (i.e. home-field advantage occurs).

\section{Material and methods}

\subsection{Study site}

The study site is at the Chokurdakh Scientific Tundra Station (7049'28', N, 147²9'23'” E; elevation 11 m a.s.l.) in Kytalyk Wildlife Reserve, which is located in the lowlands of the Indigirka River in northeastern Siberia, Russia. The mean annual air temperature at the nearest climate station (Chokurdakh, WMO station code 21946, $27 \mathrm{~km}$ away from the study site) is $-13.4^{\circ} \mathrm{C}(1981-2010)$, with $10.3{ }^{\circ} \mathrm{C}$ as the mean July temperature. Annual precipitation is $196 \mathrm{~mm}(1981-2010)$, of which on average $76 \mathrm{~mm}$ falls in the summer (June - August). The study area is the former lake bed of a drained thermokarst lake, which has a shallow $(20-45 \mathrm{~cm}$ ) active layer (the soil layer that thaws in the summer) underlain by thick continuous permafrost (Blok et al., 2010; Nauta et al., 2015).

The vegetation surrounding the Chokurdakh Scientific Tundra Station is classified as G4, consisting of tussock-sedges (i.e. graminoids), dwarf-shrubs and moss on the Circumpolar Arctic Vegetation Map (Walker et al., 2005). In the lake bed we distinguished 3 vegetation types: vegetation dominated by the tussock-forming sedge E. vaginatum (> 70\% cover); vegetation dominated by the deciduous shrub B. nana (> 70\% cover) and a mixed vegetation of both species (Wang et al., 2016b). Other co-existing species with minor abundances include the grasses Arctagrostis latifolia (R. Br.) Griseb and Calamagrostis holmii Lange, the sedge Carex aquatilis Wahlenberg, the deciduous shrub Salix pulchra Cham, the evergreen shrubs Vaccinium vitis-idaea $\mathrm{L}$ and Rhododendron subarcticum 
Harmaja. A moss layer with some lichen species is present throughout the study area (Blok et al., 2010).

\subsection{Experimental design}

We focused on the two dominant plant species from different PFTs, the graminoid E. vaginatum and the deciduous shrub B. nana. For E. vaginatum it was possible to collect dead roots as its roots are mostly annual (Chapin, 1974; Sullivan et al., 2007; but see Iversen et al., 2015) and white-colored when alive, and become black after senescence. Roots of E. vaginatum grow from the base of the tiller and are unbranched with a uniform diameter of $\sim 1 \mathrm{~mm}$ along the length, so all E. vaginatum roots were considered fine roots. In addition, B. nana roots are usually ectomycorrizal while E. vaginatum roots are non-mycorrhizal (Iversen et al., 2015). We also included senesced leaves of E. vaginatum (referred to as dead leaves here) to compare the decomposition leaf and root litter of this species. It was impossible to collect shrub root litter (B. nana dead roots) from the soil, because roots are not likely to shed discretely like leaves, but rather gradually lose functions and become colonized by decomposers as they age (Hobbie et al., 2010). Hence, for B. nana we only could collect live fine roots ( $<1 \mathrm{~mm}$ in diameter) (referred to as live roots in the text). To reliably compare root and leaf decomposition for B. nana, we also included leaves that were alive at the time of sampling (e.g. green; referred to as live leaves here). To reliably compare decomposition of the two species, we also included live leaves and live roots of E. vaginatum, and dead leaves of B. nana. In total we included seven litter types in this experiment: live and dead leaves of E. vaginatum and B. nana, live and dead roots of the E. vaginatum, and live roots of B. nana.

Due to logistic constraints, the litters were collected in different years and dried differently (see Table S1 for an overview). Three litter (live leaves of $E$. vaginatum and $B$. nana, and live roots of $B$. nana) were collected in July 2013 from the 8 blocks where the litter bags would be buried in (see below). E. vaginatum live leaves were collected in the E. vaginatum dominated vegetation, and $B$. nana live leaves and live roots were collected in B. nana dominated vegetation. Live leaves of the two species were collected by clipping leaves from leaf bases of E. vaginatum and B. nana shoots. Live 
fine roots of $B$. nana were collected by taking soil cores from the $B$. nana dominated vegetation and picking out roots manually with forceps (Wang et al., 2016b). As mentioned above, B. nana roots are not likely to shed discretely, so it is possible that the roots from B. nana classified as 'alive' contained some dead roots. However, when collecting B. nana roots, roots that were darker in color and easily torn apart were excluded. Thus, dead roots should only account for a very minor part of the samples. The samples collected in 2013 were oven dried at $65^{\circ} \mathrm{C}$ for $72 \mathrm{~h}$ after collection and stored in dry conditions until the start of the decomposition experiment.

The other four litter types (live leaves, dead leaves and dead roots of E. vaginatum, and dead leaves of B. nana) were collected in July 2015 at a location close to the experimental plots. Dead leaves of the two species were collected from the ground underneath the E. vaginatum dominated or B. nana dominated vegetation, respectively. As dead leaves of B. nana on the soil surface were probably recently shed, we collected dead E. vaginatum leaves that were still standing up-right (assuming that older dead leaves would be lying close to the ground) to minimize the age difference of the two species' leaf litter we collected. Live and dead roots of E. vaginatum were collected in the center of tussocks formed by E. vaginatum. Roots of E. vaginatum were either white (live) or black (dead), nonwoody, unbranched, and densely clustered underneath the tussock. The samples collected in July 2015 were air-dried around $10{ }^{\circ} \mathrm{C}$ for 24 hours prior to filling the litter bags.

These differences in collection time and processing could potentially affect our results. To take this into account, we focused on pairwise comparisons of litter collected in the same year (e.g. dead leaves of B. nana and E. vaginatum) as much as possible. In the discussion, we will critically evaluate the potentially confounding effects of differences in collection time and processing on our conclusions.

E. vaginatum leaves and roots, both live and dead, were cut to pieces of $3-5 \mathrm{~cm}$ long to fit in the litter bags. Samples of each litter type were mixed and then carefully placed into litterbags, which were $10 \times 10 \mathrm{~cm}$ made from nylon mesh with a $0.5 \mathrm{~mm}$ mesh size (Top Zeven B.V., the Netherlands). Each litter bag contained one type of litter with approximately $0.4 \mathrm{~g}$ dry weight. We recorded the initial weight of each sample before putting it to a litter bag. To close the litter bags, they were folded and staple-sealed with stainless steel staples. 
Litter bags were buried in the three vegetation types. The three vegetation types differ in abiotic factors, with E. vaginatum vegetation higher in soil moisture (volumetric moisture content $51 \%, 39 \%$, $24 \%$ in the late growing season, for E. vaginatum, mixture, and B. nana vegetation respectively) and exchangeable nutrients (total inorganic N 55, 30, $26 \mu \mathrm{g} \mathrm{g}^{-1}$ resin, available P 5, 3, $3 \mu \mathrm{g} \mathrm{g}^{-1}$ resin, $\mathrm{K}$ $124,90,50 \mu \mathrm{g} \mathrm{g}^{-1}$ resin, for E. vaginatum, mixture, and B. nana vegetation respectively; see Wang et al., 2016b). In the study area, eight blocks were selected in which all three vegetation types were close to each other ( 3 - $10 \mathrm{~m}$ distance). Each block was $40-140 \mathrm{~m}$ away from the next block. In each of the 24 plots, seven litter bags (representing the different litter types) were buried. In total, we buried 168 litter bags ( 7 litter types $\times 8$ blocks $\times 3$ vegetation types) on 6 July 2015. Before being buried into the soil, the litter bags were moderately moisturized for 10 minutes. A spade was used to cut a gap in the soil with a $45^{\circ}$ angle to the moss surface, and then one litter bag was placed at a depth of $5 \mathrm{~cm}$ from the moss surface to the upper edge of the litter bag.

After 38 days, on 13 August 2015, the litter bags were harvested. After the litter bags were gently removed from the soil, organic matter and soil on the surface of the litter bags was carefully brushed off. The litter bags were stored in paper envelopes and air-dried in the field, then they were transported to the Netherlands, where they were oven-dried at $60^{\circ} \mathrm{C}$ for at least 48 hours and weighed. Mass loss was calculated as the difference between the initial dry weight and the final dry weight, divided by the initial dry weight. To determine the water content of each litter type in the initial weight, additional six samples of each litter type (four samples for B. nana live roots, see section 2.3), with known initial weight at the time of filling the litter bags, were oven-dried and weighed at Wageningen University, the Netherlands, and then average water contents were calculated. Initial weights were corrected for their water content when calculating mass loss.

\subsection{Litter quality}

To determine the relationship between decomposition and litter quality, the chemical composition of the seven litter types was determined. For each litter type, six samples (four for B. nana live roots due to a limited amount of samples) were taken to measure the initial tissue moisture content (see 
section 2.2) and litter quality. Three samples of each litter type were then used to analyze the initial carbon, nitrogen, and phosphorus concentration. The other three samples (one sample for $B$. nana live roots) were used for lignin analysis. Carbon and nitrogen concentrations were determined with an elemental analyzer (Fisons EA 1108 CHN-O). Phosphorus concentration was determined with a segmented flow analyzer (SKALAR SAN Plus System, Breda, The Netherlands) after digestion with $\mathrm{H}_{2} \mathrm{SO}_{4}$-salicylic acid- $\mathrm{H}_{2} \mathrm{O}_{2}$ and selenium (Novozamsky et al., 1983). Acid detergent lignin was determined with Ankom 220 Fiber Analyzer (Ankom Technology, USA). C:N, C:P, lignin:N, lignin:P ratios were calculated. Because lignin and $\mathrm{N}$ and $\mathrm{P}$ concentrations were measured in separate samples, lignin: $\mathrm{N}$ and lignin:P ratios were calculated using mean values of lignin and $\mathrm{N}$ and $\mathrm{P}$ concentrations in each litter type.

\subsection{Calculations and statistical analysis}

Mass loss data of the tissue types which we had for both species, i.e., live leaves, live roots, and dead leaves of the two species, were used to test HFA. Home-field advantage (HFA) was calculated following the method described in Ayres et al. (2009):

$A_{R M L a}=\frac{A_{a}}{A_{a}+B_{a}} \times 100$

$\mathrm{HFAI}=\left[\frac{A_{R M L a}+B_{R M L b}}{2} / \frac{A_{R M L b}+B_{R M L a}}{2}\right] \times 100-100$

in which $A_{R M L a}$ is the relative mass loss of species $A$ at site $a, A_{a}$ and $B_{a}$ are the percent mass loss of species $A$ and $B$ at site $a$. HFAIs were calculated separately for live and dead leaf, and live root litter for each block in the field. The formula controls for inherent habitat differences in decomposition, i.e., in one habitat the decomposition of most litter may be faster than in other habitats. Note that this formula only tests for the presence of a general HFA at the site and it does not quantify the HFA for an individual species. To calculate the HFA for individual species requires three or more reciprocally transplanted species (Ayres et al., 2009), which is beyond the scope of this study.

We used linear mixed effects models (LMM) to take into account that mass loss of samples in the same plot or block are not fully independent. As the experimental design in terms of litter species and 
dead $v s$ live plant material was not fully balanced (because we did not include B. nana dead roots), we tested live and dead plant material separately. In the model for live leaves and roots, vegetation type, species and tissue type (leaf, root) were included as fixed effects. In the model for dead leaves and roots, vegetation type and litter type (E. vaginatum leaf, E. vaginatum root, B. nana leaf) were included as fixed effects. In both models block and plot were included as random effects with a nested structure (plot within block). Mass loss data were ln transformed. Least significance difference (LSD) method was used for post hoc tests when an effect was significant in one of the models.

To test if the HFAI for each litter type is significantly larger than zero and if it differed significantly between tissue types, we ran a linear mixed model with litter type as fixed effect and block as random effect.

Litter quality was compared among the seven litter types using a model with litter type as fixed factor, block and plot as random factors with nested structure for each chemical characteristic. To determine relationships between litter quality and litter mass loss, linear regression models were fitted to the average mass loss of each litter type, using important chemical characteristics, including nitrogen, phosphorus, lignin concentration, and $\mathrm{C}: \mathrm{N}, \mathrm{C}: \mathrm{P}$, lignin:N, lignin:P ratios as predictors. We also calculated the AIC (Akaike information criterion) values and Akaike weight of each model to evaluate which chemical characteristics best explained mass loss. The lowest AIC indicates the most preferable among a set of models based on the goodness of fit and the number of parameters (Burnham and Anderson, 2004), and an Akaike weight is the probability that a model is the actual best model among a set of models (Wagenmakers and Farrell, 2004).

\section{Results}

\subsection{Mass loss of leaf and root litter and home-field advantage}

When focusing on live leaves and roots, differences in mass loss between the two species depended on tissue type (roots vs. leaves; significant interaction of species $\times$ tissue; Table 1). Leaves of the two species showed a similar mass loss $\left(F_{1,42}=0.7, P=0.424\right)$, but mass loss of $E$. vaginatum live roots 
was significantly higher than that of $B$. nana live roots $\left(F_{1,21}=747, P<0.001\right.$; Fig. 1a). Vegetation type effects on mass loss significantly differed between the two species (significant interaction of species $\times$ vegetation; Table 1): live leaves and roots of E. vaginatum had similar mass losses in the three types of vegetation $\left(F_{2,30}=0.4, P=0.657\right)$, whereas live roots (but not leaves) of $B$. nana had significantly larger mass losses in $B$. nana vegetation than in $E$. vaginatum vegetation $\left(F_{2,21}=4.2, P=\right.$ 0.03; Fig. 1a).

\section{Table 1}

Effects of vegetation, species and tissue (leaf/root) on live litter mass loss.

\begin{tabular}{lrrc}
\hline Source & df & $F$ value & $P$ value \\
\hline Vegetation & 2 & 1.4 & 0.259 \\
Species & 1 & 264.3 & $<0.001^{*}$ \\
Tissue & 1 & 40.9 & $<0.001^{*}$ \\
Vegetation $\times$ species & 2 & 4.2 & $0.019^{*}$ \\
Vegetation $\times$ tissue & 2 & 0.8 & 0.441 \\
$\begin{array}{l}\text { PFT } \times \text { tissue } \\
\text { Vegetation } \times \text { species } \times\end{array}$ & 1 & 310.4 & $<0.001^{*}$ \\
tissue & 2 & 0.2 & 0.829 \\
\hline
\end{tabular}

When focusing on dead leaves and roots, decomposition of different litter types was significantly different (Table 2): mass loss of B. nana and E. vaginatum leaves was similar, but both were significantly higher than $E$. vaginatum roots $(P=0.002$ and $P<0.001$ respectively; Fig. 1 b). Similar to live plant tissues, vegetation type effects on mass loss depended on species (significant interaction of litter type $\times$ vegetation; Table 2). Dead roots of $E$. vaginatum decayed significantly faster in $E$. vaginatum vegetation than in $B$. nana vegetation $\left(F_{2,30}=5.1, P=0.013\right)$, while live roots and dead leaves of B. nana had significantly larger mass loss in B. nana vegetation than in E. vaginatum vegetation $\left(F_{2,21}=4.5, P=0.023\right)$. As indicated by these significant interactions between vegetation type and species, we found a clear home-field advantage for our litter types. This effect was significantly greater than zero for live roots and dead leaves (see Fig. S1). 
Table 2

Effects of vegetation and dead litter type (E. vaginatum and B. nana leaves, E. vaginatum roots) on mass loss.

\begin{tabular}{lccc}
\hline Source & df & $F$ value & $P$ value \\
\hline Vegetation & 2 & 0.4 & 0.697 \\
Litter type & 2 & 12.4 & $<0.001^{*}$ \\
Vegetation $\times$ litter type & 4 & 4.2 & $0.005^{*}$ \\
\hline
\end{tabular}

(a)

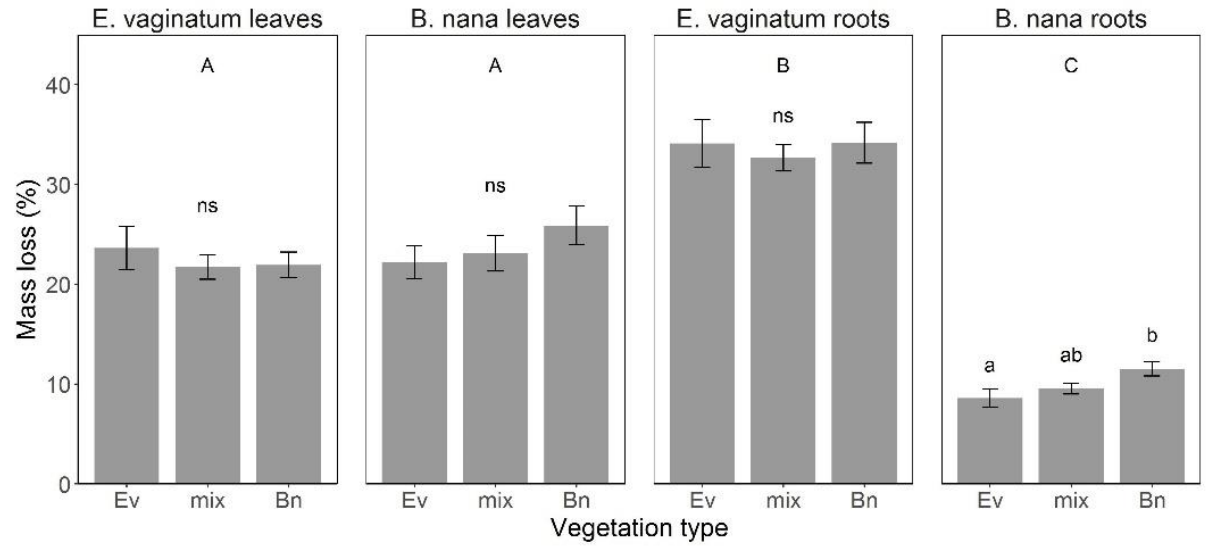

(b)
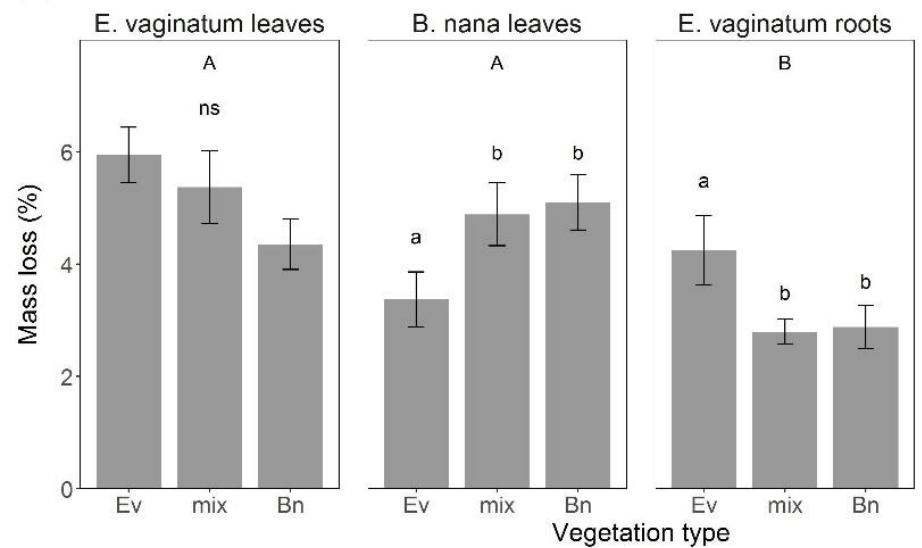

277

Fig. 1. Mass loss of live (a) and dead (b) litter types in the three vegetation types: E. vaginatum (Ev), mixed (mix) and B. nana (Bn). Bars are means $\pm \mathrm{SE}, \mathrm{n}=8$. Scales of $\mathrm{y}$-axes in (a) and (b) are different as mass loss of dead litter was much smaller. Capital letters represent significant $(P<0.05)$ pairwise differences in mass loss between litter types for live and dead litter respectively; lowercase letters represent significant $(P<0.05)$ pairwise differences in mass loss between vegetation types within litter types. 


\subsection{Relations between mass loss and litter quality}

The seven litter types differed significantly in nitrogen, phosphorus and lignin content and related ratios (Table 3). In general, B. nana litter was characterized by higher lignin concentrations than litter of E. vaginatum. Not surprisingly, dead plant material showed lower nitrogen and phosphorus concentrations than live plant material, but dead roots and leaves of E. vaginatum had particularly low nitrogen and phosphorus contents (Table 3). Across all litter types, nitrogen content differed up to 5 fold (between B. nana live leaves and E. vaginatum dead roots), whereas phosphorus content differed up to 17 fold (between B. nana live leaves and E. vaginatum dead leaves; Table 3).

The average mass loss of a litter type was significantly related to litter characteristics involving phosphorus. Mass loss significantly increased with increasing $\mathrm{P}$ concentration, and decreased with the C:P and lignin:P ratios (Fig. 2). Mass loss also significantly decreased, albeit weaker, with the lignin: $\mathrm{N}$ ratio. No significant relationships between mass loss and nitrogen concentration, $\mathrm{C}: \mathrm{N}$ and lignin concentration were found (Fig. 2). Model comparisons revealed that phosphorus concentration and lignin:P were the best predictors for mass loss of the different litters in the tundra (Table S2).

\section{Table 3}

Initial chemical characteristics of the different litter types. Different letters indicate differences between litter types using Tukey HSD post hoc method. $\mathrm{N}=3$ except for lignin concentration in $B$. nana roots. Lignin:N and lignin:P were calculated with mean values of lignin and N/P concentration as they were from separate samples.

\begin{tabular}{cccccccc}
\hline $\begin{array}{c}\text { Chemical } \\
\text { characteristics }\end{array}$ & $\begin{array}{c}\text { E. vaginatum } \\
\text { live leaves }\end{array}$ & $\begin{array}{c}\text { E. vaginatum } \\
\text { dead leaves }\end{array}$ & $\begin{array}{c}\text { B. nana live } \\
\text { leaves }\end{array}$ & $\begin{array}{c}\text { B. nana dead } \\
\text { leaves }\end{array}$ & $\begin{array}{c}\text { E. vaginatum } \\
\text { live roots }\end{array}$ & $\begin{array}{c}\text { E. vaginatum } \\
\text { dead roots }\end{array}$ & $\begin{array}{c}\text { B. nana live } \\
\text { roots }\end{array}$ \\
\hline $\mathrm{C}(\%)$ & $45.9 \pm 0.2^{\mathrm{ab}}$ & $45.7 \pm 0.2^{\mathrm{ab}}$ & $47.0 \pm 2.6^{\mathrm{ab}}$ & $50.2 \pm 0.3^{\mathrm{a}}$ & $43.2 \pm 0.1^{\mathrm{b}}$ & $46.8 \pm 0.2^{\mathrm{ab}}$ & $47.4 \pm 1.0^{\mathrm{ab}}$ \\
& & & & & & & \\
Lignin $(\%)$ & $3.4 \pm 0.02^{\mathrm{d}}$ & $4.7 \pm 0.1^{\mathrm{d}}$ & $18.9 \pm 0.5^{\mathrm{b}}$ & $35.3 \pm 0.2^{\mathrm{a}}$ & $3.2 \pm 0.3^{\mathrm{d}}$ & $11.4 \pm 0.8^{\mathrm{c}}$ & 34.6 \\
$\begin{array}{c}\mathrm{N} \\
\left(\mathrm{mg} \mathrm{g}^{-1}\right)\end{array}$ & $16.5 \pm 0.6^{\mathrm{b}}$ & $6.5 \pm 0.8^{\mathrm{c}}$ & $27.2 \pm 1.6^{\mathrm{a}}$ & $12.8 \pm 0.5^{\mathrm{b}}$ & $13.3 \pm 1.0^{\mathrm{b}}$ & $5.9 \pm 0.9^{\mathrm{c}}$ & $15.1 \pm 1.4^{\mathrm{b}}$
\end{tabular}




$\begin{array}{cccccccc}\begin{array}{c}\mathrm{P} \\ \left(\mathrm{mg} \mathrm{g}^{-1}\right)\end{array} & 2.77 \pm 0.04^{\mathrm{c}} & 0.20 \pm 0.02^{\mathrm{f}} & 3.37 \pm 0.01^{\mathrm{a}} & 0.69 \pm 0.04^{\mathrm{e}} & 3.05 \pm 0.03^{\mathrm{b}} & 0.21 \pm 0.01^{\mathrm{f}} & 1.15 \pm 0.04^{\mathrm{d}} \\ \mathrm{N}: \mathrm{P} & 6.0 \pm 0.3^{\mathrm{a}} & 32.0 \pm 2.7^{\mathrm{d}} & 8.1 \pm 0.5^{\mathrm{a}} & 18.8 \pm 1.8^{\mathrm{bc}} & 4.4 \pm 0.4^{\mathrm{a}} & 28.2 \pm 4.7^{\mathrm{cd}} & 13.2 \pm 1.2^{\mathrm{ab}} \\ \mathrm{C}: \mathrm{N} & 27.9 \pm 1.0^{\mathrm{b}} & 72.4 \pm 9.4^{\mathrm{a}} & 17.3 \pm 0.4^{\mathrm{c}} & 39.4 \pm 1.8^{\mathrm{b}} & 32.8 \pm 2.7^{\mathrm{b}} & 82.0 \pm 10.9^{\mathrm{a}} & 31.9 \pm 3.5^{\mathrm{b}} \\ \mathrm{C}: \mathrm{P} & 166 \pm 2^{\mathrm{d}} & 2277 \pm 181^{\mathrm{a}} & 139 \pm 8^{\mathrm{d}} & 735 \pm 44^{\mathrm{b}} & 142 \pm 1^{\mathrm{d}} & 2212 \pm 132^{\mathrm{a}} & 413 \pm 18^{\mathrm{c}} \\ \text { Lignin:N } & 2.1 & 7.2 & 7.0 & 27.6 & 2.4 & 19.2 & 22.9 \\ \text { Lignin:P } & 12.5 & 229.7 & 56.1 & 513.5 & 10.4 & 535.9 & 301.1\end{array}$
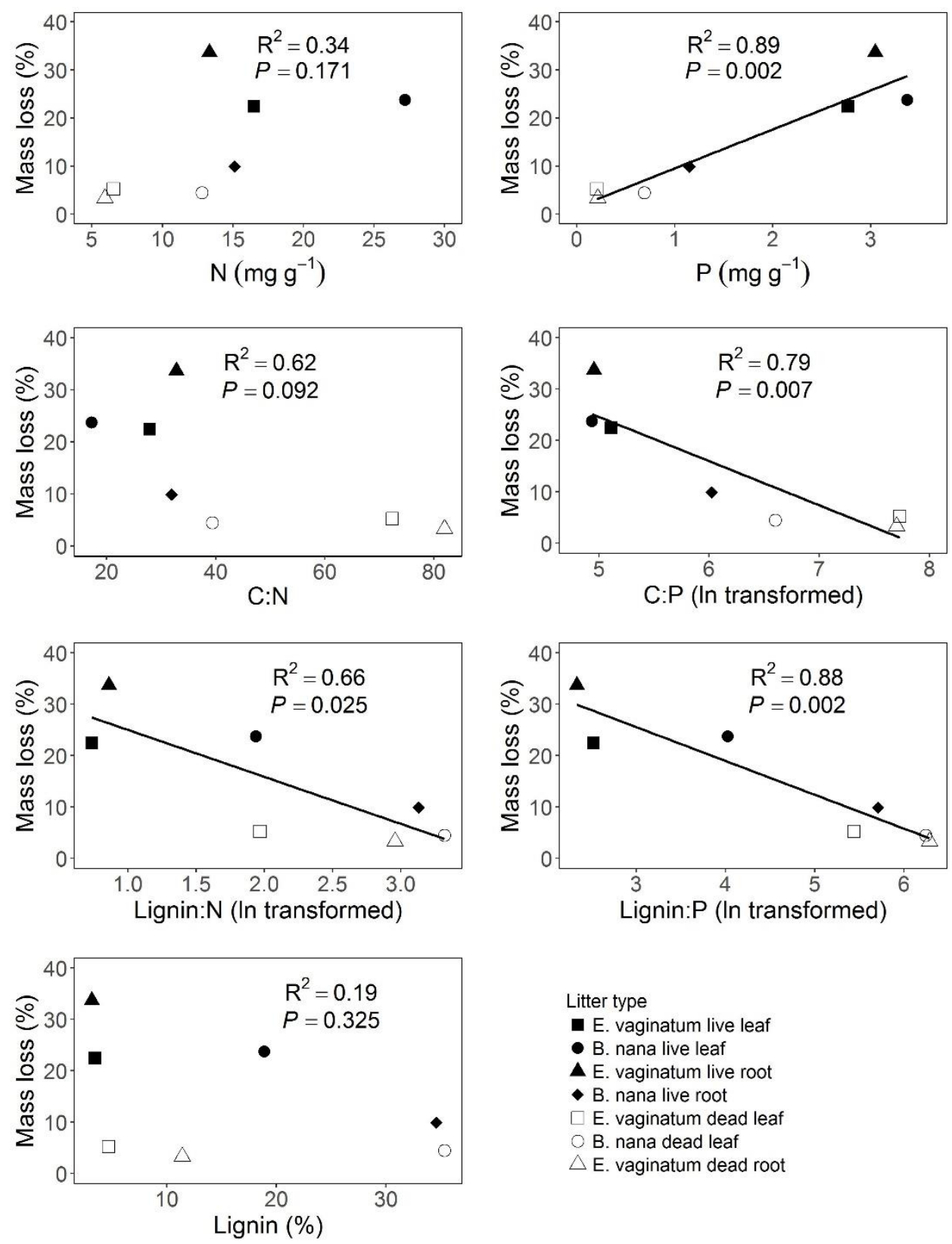

\section{Litter type}

E. vaginatum live leaf

- B. nana live leaf

$\boldsymbol{\Delta}$ E. vaginatum live root

- B. nana live root

$\square$ E. vaginatum dead leaf

B. nana dead leaf

$\triangle E$. vaginatum dead root 
307 Fig. 2. Relationships between mass loss of the seven litter types and their initial chemical 308 characteristics. Relationships between mass loss and litter quality were particularly strong for P-related 309 characteristics (right column). Symbols show average mass loss $(n=24)$ and chemical characteristic 310 values ( $\mathrm{n}=1$ for lignin content of $B$. nana dead roots and lignin: $\mathrm{N}$, lignin:P; $\mathrm{n}=3$ for other 311 characteristics; see Table 3). 


\section{Discussion}

The decomposition of root litter was different between the two species, in contrast to the decomposition of leaf litter. The differences in mass loss rate among the litter types were significantly correlated to phosphorus content, not to nitrogen content. In addition, we found evidence for homefield advantage in litter decomposition: litter of the two species decomposed faster in vegetation in which they were dominant. As root litter constitutes a considerable fraction of the organic matter input in this system (Freschet et al., 2013), the difference in root decomposition rates between the two dominant species at the research site suggests that changes in carbon dynamics with vegetation shifts in tundra ecosystems will largely depend on root decomposition.

\subsection{Decomposition of leaves and roots of the two species}

The decomposition of leaf litter did not differ between the two species. This was true for both dead and live leaves. However, the decomposition of live roots was significantly different between the two species, although we cannot exclude a potential small effect of the inclusion of some $B$. nana dead roots in the 'live' root samples, which might have led to an overestimation of the difference between the decomposition of E. vaginatum and B. nana roots. These results only partly confirm our hypotheses that root decomposition is slower than leaf decomposition and that the decomposition of $B$. nana litter is slower than that of $E$. vaginatum litter, and they suggest that we need to consider the differences between tissue types and species or PFTs, as PFTs are a reasonable classification of major plant species in the tundra (Chapin et al., 1996), at the same time.

Shrub litter is generally thought to be less decomposable than graminoid litter, as the former has a higher lignin concentration and C:N ratio (Cornelissen et al., 2007; Hobbie, 1996; Zhang et al., 2008). In our study, this is only the case for root litter, as leaf litter of the two species exhibited similar mass loss rates. $B$. nana leaves had higher nitrogen and phosphorus concentrations than E. vaginatum leaves, however, the former also had higher lignin concentration, which could offset the positive effects of higher nutrient concentrations on the litter decomposition. 
Mass loss of live roots of the two species showed large difference. B. nana fine roots in our samples are mainly first- and second-order roots, which fact could make the actual decomposition of the whole root system a bit higher, as some studies found that lowest order roots decay slower that higher order roots (Fan and Guo, 2010; Goebel et al., 2011). However, the lower turnover rates of higher order roots (McCormack et al., 2015) make it unlikely to offset or reverse this difference we found. Therefore, we suggest that root decomposition in the tundra can differ between shrubs and graminoids, at least in the early stage of decomposition for the two dominant species. However, in the later stages of decomposition the differences may change, as the decomposition of E. vaginatum dead roots decreased drastically. Our results emphasize that it is important to consider root litter separately from leaf litter when comparing different species or PFTs, even when the decomposition of leaf litter does not show differences.

Many studies have shown that root litter is less decomposable than leaf litter as roots contain more chemically recalcitrant substances (Freschet et al., 2012; Freschet et al., 2013; Gorissen and Cotrufo, 2000; Ma et al., 2016). In our study this is only partly true, as E. vaginatum live leaves were decomposed slower than its live roots. However, the dead leaves of the E. vaginatum decomposed faster than its dead roots. This discrepancy between live and dead plant material when comparing leaf and root decomposition illustrates that live roots may not necessarily be a good predictor of dead root decomposition, particularly for E. vaginatum roots, and that conclusions about decomposition based on live tissues of different plants should be treated with caution, especially if species differ in characteristics such as nutrient resorption efficiency (Scheffer and Aerts, 2000; Snyder and Rejmánková, 2015).

Litter quality (e.g., nitrogen and lignin concentration, $\mathrm{C}: \mathrm{N}$ ratio) is one of the most important factors in decomposition from grassland to forest ecosystems (Cornwell et al., 2008; Freschet et al., 2012; Zhang et al., 2008). It is well known that nutrient concentrations, particularly nitrogen, are among the best predictors during the early stage of decomposition, while lignin is the best predictor during later stages (Berg and McClaugherty, 2014). In our study, traits related to phosphorus content were identified as the main drivers of litter decomposition, suggesting that at least the early phases of 
decomposition are phosphorus-limited. This finding is consistent with another study (Beermann et al., 2014) which suggested that at the research site nitrogen mineralization and fixation by bacteria are limited by phosphorus availability. On the other hand, according to Koerselman and Meuleman (1996), an N:P ratio below 14 indicates nitrogen limitation for plant growth. The low N:P ratio of green leaves in our study $(6.0-8.1$; Table 3$)$ suggests that plant growth was limited by nitrogen availability. The explanation for the limitation of microbial growth and plants growth by different elements could be that the accessibility to phosphorus is different for them. While microbes in the shallow soil are limited by phosphorus, graminoids can exploit the deep soil, where larger amounts of phosphorus are available (Beermann et al., 2014; Chapin et al., 1978). Shrubs can depend on mycorrhizal fungi to absorb phosphorus from the deep soil (Bolan, 1991; Landeweert et al., 2001). Efficient phosphorus resorption by plants from senescing plant parts could be another explanation of the phosphorus limitation of microbes. However, we could not examine this hypothesis with our data as the dead leaves/roots were not freshly senesced and we do not know to what extent the massive differences in phosphorus concentration and $\mathrm{N}: \mathrm{P}$ can be attributed to plant resorption and microbial mobilization, respectively.

\subsection{Home-field advantage effects on decomposition}

Decomposition of both species tended to be faster in the vegetation in which they were dominant, i.e. in their 'own' vegetation, suggesting home-field advantage effects in our study. Home-field advantage was significant for B. nana (for roots and dead leaves) and E. vaginatum (dead leaves), even though there are big differences in decomposability between these litter types. In fact, in our study the site effects are stronger for dead than for live tissue (i.e. stronger for tissues with lower decomposability; see Fig S1), consistent with the idea that litter with low decomposability requires more specialized decomposers (Ayres et al., 2009; Milcu and Manning, 2011). However, in a subarctic tundra in northern Sweden, Veen et al. (2015b) found no significant home-field advantage in the decomposition of leaf litter. The reason could be that in their experiment they used a mixture of litters 
from different plant species, therefore the HFA effect at the species level, as shown in our study, could be masked by the community level measurement.

The E. vaginatum and B. nana vegetation in our study differ in abiotic factors. E. vaginatum vegetation is wetter and more nutrient-rich than the B. nana vegetation (Nauta et al., 2015; Wang et al., 2016b). However, the lack of overall vegetation effects on mass loss suggests that abiotic factors are not decisive in our experiment. Instead, the different environmental conditions may have shaped different microbial communities, that also determine the home-field advantage effects in litter decomposition (Wallenstein et al., 2007).

\subsection{Influences of the collection years and drying of litter}

As mentioned in the methods, there were differences in litter collection and processing between live and dead plant material. All live materials, except E. vaginatum live roots, were collected in 2013, dried at $65^{\circ} \mathrm{C}$ and stored until the decomposition experiment, whereas all dead materials were collected in 2015 and air-dried. E. vaginatum live roots were collected in 2015, together with the collection of dead materials, and air-dried. This could potentially affect our results, but we avoided this problem by drawing conclusions based on comparisons of litter types collected in the same year (i.e., with the same drying process). The only exception are the live roots. E. vaginatum live roots were collected in 2015, whereas those of B. nana were collected in 2013. This could potentially affect our first conclusion that root decomposition differs between E. vaginatum and B. nana. To check this, we compared the initial $\mathrm{P}$ and $\mathrm{N}$ concentrations in E. vaginatum live roots of both years (a small amount of E. vaginatum live roots was also collected in 2013 and dried at $65^{\circ} \mathrm{C}$ in another experiment at the same site), and found no significant differences between years for $\mathrm{P}(2.97 \pm 0.04$ vs $3.05 \pm 0.03$ $\mathrm{mg} / \mathrm{g}, P=0.85)$, and a marginally significant difference for $\mathrm{N}(17.0 \pm 1.6 \mathrm{vs} 13.3 \pm 1.0 \mathrm{mg} / \mathrm{g}, P=$ 0.09). Given these small differences, it is unlikely that the large (3-fold) difference in mass loss we report for B. nana and E. vaginatum roots (Fig. 1) is affected by differences in year of collection or drying. 
Across all seven litter types, $\mathrm{P}$ concentration was the main driver of differences in decomposition

(Fig. 2). However, as can also be seen in this figure, the three dead litters collected in 2015 (except $E$. vaginatum live root) did show lower mass loss than the ones collected in 2013, suggesting that the $\mathrm{P}$ concentration effect could also be driven by year of litter collection. We checked this by comparing our litter quality model to one that explains mass loss by year of collection. The results show that year did not have a significant effect on decomposition $\left(F_{1,5}=0.55, P=0.49\right)$, which is not surprising given that litters collected in 2015 included both E. vaginatum live roots and three dead materials and thus the variance of mass loss was large. In addition, when comparing the AIC values of both models it was clear that litter quality ( $\mathrm{P}$ and lignin:P) performed better ( $\mathrm{AIC}=-20.3$ and -19.9 , respectively) than the year model $(\mathrm{AIC}=-5.8)$. Thus, although we cannot completely rule out that year of collection affected mass loss, it is more likely that decomposition is indeed driven by litter quality. This is supported by the lack of difference in $\mathrm{P}$ content between E. vaginatum live roots collected in 2013 and 2015, as explained above.

\subsection{Implications for carbon dynamics in the tundra}

There is major concern that tundra ecosystems might shift from a carbon sink to a carbon source with warmer climates (Belshe et al., 2013; Oechel et al., 1993; Webb et al., 2016). A warmer climate will increase primary productivity of tundra vegetation and thus increase carbon uptake by the ecosystem (Epstein et al., 2012; Hill and Henry, 2011; Verbyla, 2008). On the other hand, higher temperatures also accelerate decomposition and thus increase carbon emission from the soil (Davidson and Janssens, 2006; Hobbie, 1996). The balance between these two changes will determine whether tundra ecosystems will continue to act as a carbon sink or will shift to a carbon source. These changes in carbon dynamics can be modified by shifts in tundra vegetation composition due to climate warming. The home-field advantage in litter decomposition in our study suggests that litter decomposition rates may be temporarily reduced when vegetation shifts occur. However, whether this reduction in decomposition due to home-field advantage can at least temporarily offset the increase in decomposition due to climate warming needs further investigation. 
Shifts in vegetation composition also affect decomposition via changes in litter quality (Cornelissen et al., 2007). Focusing on the aboveground tissues, our study does not provide evidence for vegetation induced changes in decomposition rates, as the decomposability of leaf litter did not differ between the two species. However, root litter decomposition was lower for B. nana than for E. vaginatum, at least in the early stage. Also, it is known that root turnover rates of shrubs are lower than that of graminoids in the tundra (Mack et al., 2004; Shaver and Chapin, 1991; Sullivan et al., 2007). When extrapolating this finding, it would suggest that shrub expansion with increasing temperatures could reduce decomposition and increase carbon storage. However, it may be important to consider that graminoids roots typically grow deeper than shrubs (Miller et al., 1982; Shaver and Chapin, 1991; Wang et al., 2016b). As deeper soil layers will be colder, decomposition of graminoid roots may be slower than observed in litter bag studies in the upper soil layer. This is illustrated by the observation that yedoma (windblown dust, deposited during the glacial age) permafrost contains almost intact graminoid roots (Zimov et al., 2006). To accurately predict the long-term effects of vegetation shifts on decomposition and the carbon balance, detailed knowledge of the temporal dynamics in root turnover and decomposition at different soil depths in relation to soil temperature are needed.

\section{Conclusion}

Our study shows that although leaf litter decomposition did not differ between the two dominant species, root litter decomposition was significantly higher for the graminoid E. vaginatum than for the shrub B. nana. The differences we found in decomposability could be mainly attributed to litter traits related to phosphorus. In addition, home-field advantage effects were found, which may lead to temporary reductions in litter decomposition when vegetation shifts occur. Our results indicate that root decomposition can be an important driver of changes in carbon dynamics when vegetation shifts and consequently plant litter changes in the tundra. The large difference between the mass loss of the live and dead plant materials, particularly between the live and dead E. vaginatum roots, suggests that only looking at the initial phase of decomposition does not give a clear indication of decomposition rate over time. 


\section{Acknowledgements}

We thank staff of IBPC, Yakutsk, and staff of the Regional Inspection of Nature Protection of Allaikhovsky Region, Chokurdakh, for logistic support and assistance. We thank Hongmei Chen for providing litter bags used in the experiment. PW acknowledges financial support from China Scholarship Council (CSC, No.201206040062), MH and LM acknowledge support from The Netherlands Organisation for Scientific Research (NWO-ALW, VIDI grants 864.09.014 and 864.15.006).

\section{References}

Aerts, R., 2006. The freezer defrosting: global warming and litter decomposition rates in cold biomes. Journal of Ecology 94, 713-724.

Ayres, E., Steltzer, H., Simmons, B.L., Simpson, R.T., Steinweg, J.M., Wallenstein, M.D., Mellor, N., Parton, W.J., Moore, J.C., Wall, D.H., 2009. Home-field advantage accelerates leaf litter decomposition in forests. Soil Biology and Biochemistry 41, 606-610.

Beermann, F., Teltewskoi, A., Fiencke, C., Pfeiffer, E.-M., Kutzbach, L., 2014. Stoichiometric analysis of nutrient availability (N, P, K) within soils of polygonal tundra. Biogeochemistry 122, 211-227.

Belshe, E.F., Schuur, E.A.G., Bolker, B.M., 2013. Tundra ecosystems observed to be $\mathrm{CO}_{2}$ sources due to differential amplification of the carbon cycle. Ecology Letters 16, 1307-1315.

Berendse, F., Bobbink, R., Rouwenhorst, G., 1989. A comparative study on nutrient cycling in wet heathland ecosystems. II. Litter decomposition and nutrient mineralization. Oecologia 78, 338-348.

Berendse, F., Oudhof, H., Bol, J., 1987. A comparative study on nutrient cycling in wet heathland ecosystems. I. Litter production and nutrient losses from the plant. Oecologia 74, 174-184.

Berg, B., McClaugherty, C., 2014. Plant Litter. Decomposition, Humus Formation, Carbon Sequestration, Third ed. Springer-Verlag Berlin Heidelberg.

Birouste, M., Kazakou, E., Blanchard, A., Roumet, C., 2011. Plant traits and decomposition: are the relationships for roots comparable to those for leaves? Annals of Botany.

Blok, D., Heijmans, M.M.P.D., Schaepman-Strub, G., Kononov, A.V., Maximov, T.C., Berendse, F., 2010. Shrub expansion may reduce summer permafrost thaw in Siberian tundra. Global Change Biology 16, 12961305 .

Bolan, N.S., 1991. A critical review on the role of mycorrhizal fungi in the uptake of phosphorus by plants. Plant and Soil 134, 189-207.

Bonan, G.B., Hartman, M.D., Parton, W.J., Wieder, W.R., 2013. Evaluating litter decomposition in earth system models with long-term litterbag experiments: an example using the Community Land Model version 4 (CLM4). Global Change Biology 19, 957-974. 
Bryant, D.M., Holland, E.A., Seastedt, T.R., Walker, M.D., 1998. Analysis of litter decomposition in an alpine tundra. Canadian Journal of Botany 76, 1295-1304.

Burnham, K.P., Anderson, D.R., 2004. Multimodel inference understanding AIC and BIC in model selection. Sociological Methods \& Research 33, 261-304.

Callaghan, T., Tweedie, C., Åkerman, J., Andrews, C., Bergstedt, J., Butler, M., Christensen, T., Cooley, D., Dahlberg, U., Danby, R., Daniëls, F.A., de Molenaar, J., Dick, J., Mortensen, C., Ebert-May, D., Emanuelsson, U., Eriksson, H., Hedenås, H., Henry, G.H.R., Hik, D., Hobbie, J., Jantze, E., Jaspers, C., Johansson, C., Johansson, M., Johnson, D., Johnstone, J., Jonasson, C., Kennedy, C., Kenney, A., Keuper, F., Koh, S., Krebs, C., Lantuit, H., Lara, M., Lin, D., Lougheed, V., Madsen, J., Matveyeva, N., McEwen, D., Myers-Smith, I., Narozhniy, Y., Olsson, H., Pohjola, V., Price, L., Rigét, F., Rundqvist, S., Sandström, A., Tamstorf, M., Van Bogaert, R., Villarreal, S., Webber, P., Zemtsov, V., 2011. Multi-decadal changes in tundra environments and ecosystems: synthesis of the International Polar Year-Back to the Future Project (IPY-BTF). AMBIO 40, 705 716.

Chapin, F.S., III, 1974. Morphological and physiological mechanisms of temperature compensation in phosphate absorption along a latitudinal gradient. Ecology 55, 1180-1198.

Chapin, F.S., III, Barsdate, R.J., Barèl, D., 1978. Phosphorus cycling in alaskan coastal tundra: A hypothesis for the regulation of nutrient cycling. Oikos 31, 189-199.

Chapin, F.S., III, Bret-Harte, M.S., Hobbie, S.E., Zhong, H., 1996. Plant functional types as predictors of transient responses of arctic vegetation to global change. Journal of Vegetation Science 7, 347-358.

Cornelissen, J.H., Van Bodegom, P.M., Aerts, R., Callaghan, T.V., Van Logtestijn, R.S., Alatalo, J., Chapin, F.S., III, Gerdol, R., Gudmundsson, J., Gwynn - Jones, D., 2007. Global negative vegetation feedback to climate warming responses of leaf litter decomposition rates in cold biomes. Ecology letters 10, 619-627.

Cornwell, W.K., Cornelissen, J.H.C., Amatangelo, K., Dorrepaal, E., Eviner, V.T., Godoy, O., Hobbie, S.E., Hoorens, B., Kurokawa, H., Pérez-Harguindeguy, N., Quested, H.M., Santiago, L.S., Wardle, D.A., Wright, I.J., Aerts, R., Allison, S.D., Van Bodegom, P., Brovkin, V., Chatain, A., Callaghan, T.V., Díaz, S., Garnier, E., Gurvich, D.E., Kazakou, E., Klein, J.A., Read, J., Reich, P.B., Soudzilovskaia, N.A., Vaieretti, M.V., Westoby, M., 2008. Plant species traits are the predominant control on litter decomposition rates within biomes worldwide. Ecology Letters 11, 1065-1071.

Davidson, E.A., Janssens, I.A., 2006. Temperature sensitivity of soil carbon decomposition and feedbacks to climate change. Nature 440, 165-173.

Elmendorf, S.C., Henry, G.H.R., Hollister, R.D., Björk, R.G., Bjorkman, A.D., Callaghan, T.V., Collier, L.S., Cooper, E.J., Cornelissen, J.H.C., Day, T.A., Fosaa, A.M., Gould, W.A., Grétarsdóttir, J., Harte, J., Hermanutz, L., Hik, D.S., Hofgaard, A., Jarrad, F., Jónsdóttir, I.S., Keuper, F., Klanderud, K., Klein, J.A., Koh, S., Kudo, G., Lang, S.I., Loewen, V., May, J.L., Mercado, J., Michelsen, A., Molau, U., Myers-Smith, I.H., Oberbauer, S.F., Pieper, S., Post, E., Rixen, C., Robinson, C.H., Schmidt, N.M., Shaver, G.R., Stenström, A., Tolvanen, A., Totland, Ø., Troxler, T., Wahren, C.-H., Webber, P.J., Welker, J.M., Wookey, P.A., 2012. Global assessment of experimental climate warming on tundra vegetation: heterogeneity over space and time. Ecology Letters 15, 164175.

Enriquez, S., Duarte, C.M., Sand-Jensen, K., 1993. Patterns in decomposition rates among photosynthetic organisms: the importance of detritus C: N: P content. Oecologia 94, 457-471.

Epstein, H.E., Raynolds, M.K., Walker, D.A., Bhatt, U.S., Tucker, C.J., Pinzon, J.E., 2012. Dynamics of aboveground phytomass of the circumpolar Arctic tundra during the past three decades. Environmental Research Letters 7, 015506.

Fan, P., Guo, D., 2010. Slow decomposition of lower order roots: a key mechanism of root carbon and nutrient retention in the soil. Oecologia 163, 509-515.

Freschet, G.T., Aerts, R., Cornelissen, J.H.C., 2012. A plant economics spectrum of litter decomposability. Functional Ecology 26, 56-65. 
Freschet, G.T., Cornwell, W.K., Wardle, D.A., Elumeeva, T.G., Liu, W., Jackson, B.G., Onipchenko, V.G., Soudzilovskaia, N.A., Tao, J., Cornelissen, J.H.C., 2013. Linking litter decomposition of above- and belowground organs to plant-soil feedbacks worldwide. Journal of Ecology 101, 943-952.

Fujii, S., Takeda, H., 2010. Dominant effects of litter substrate quality on the difference between leaf and root decomposition process above- and belowground. Soil Biology and Biochemistry 42, 2224-2230.

Gholz, H.L., Wedin, D.A., Smitherman, S.M., Harmon, M.E., Parton, W.J., 2000. Long - term dynamics of pine and hardwood litter in contrasting environments: toward a global model of decomposition. Global Change Biology 6, 751-765.

Goebel, M., Hobbie, S.E., Bulaj, B., Zadworny, M., Archibald, D.D., Oleksyn, J., Reich, P.B., Eissenstat, D.M., 2011. Decomposition of the finest root branching orders: linking belowground dynamics to fine - root function and structure. Ecological Monographs 81, 89-102.

Gorissen, A., Cotrufo, M.F., 2000. Decomposition of leaf and root tissue of three perennial grass species grown at two levels of atmospheric $\mathrm{CO}_{2}$ and $\mathrm{N}$ supply. Plant and Soil 224, 75-84.

Hill, G.B., Henry, G.H.R., 2011. Responses of High Arctic wet sedge tundra to climate warming since 1980. Global Change Biology 17, 276-287.

Hobbie, S.E., 1996. Temperature and plant species control over litter decomposition in Alaskan tundra. Ecological Monographs 66, 503-522.

Hobbie, S.E., Oleksyn, J., Eissenstat, D.M., Reich, P.B., 2010. Fine root decomposition rates do not mirror those of leaf litter among temperate tree species. Oecologia 162, 505-513.

Houghton, R.A., 2007. Balancing the global carbon budget. Annu. Rev. Earth Planet. Sci. 35, 313-347.

IPCC, 2013. Climate Change 2013: The Physical Science Basis. Contribution of Working Group I to the Fifth Assessment Report of the Intergovernmental Panel on Climate Change. Cambridge University Press, Cambridge, United Kingdom and New York, NY, USA.

Iversen, C.M., Sloan, V.L., Sullivan, P.F., Euskirchen, E.S., McGuire, A.D., Norby, R.J., Walker, A.P., Warren, J.M., Wullschleger, S.D., 2015. The unseen iceberg: plant roots in arctic tundra. New Phytologist 205, 34-58.

Jones, P.D., Lister, D.H., Osborn, T.J., Harpham, C., Salmon, M., Morice, C.P.C.D., 2012. Hemispheric and large-scale land-surface air temperature variations: An extensive revision and an update to 2010. J. Geophys. Res. 117, D05127.

Koerselman, W., Meuleman, A.F.M., 1996. The vegetation N:P ratio: A new tool to detect the nature of nutrient limitation. Journal of Applied Ecology 33, 1441-1450.

Landeweert, R., Hoffland, E., Finlay, R.D., Kuyper, T.W., van Breemen, N., 2001. Linking plants to rocks: ectomycorrhizal fungi mobilize nutrients from minerals. Trends in Ecology \& Evolution 16, 248-254.

Ma, C., Xiong, Y., Li, L., Guo, D., 2016. Root and leaf decomposition become decoupled over time: implications for below- and above-ground relationships. Functional Ecology 30, 1239-1246.

Mack, M.C., Schuur, E.A.G., Bret-Harte, M.S., Shaver, G.R., Chapin, F.S., III, 2004. Ecosystem carbon storage in arctic tundra reduced by long-term nutrient fertilization. Nature 431, 440-443.

McCormack, M.L., Dickie, I.A., Eissenstat, D.M., Fahey, T.J., Fernandez, C.W., Guo, D., Helmisaari, H.S., Hobbie, E.A., Iversen, C.M., Jackson, R.B., 2015. Redefining fine roots improves understanding of below ground contributions to terrestrial biosphere processes. New Phytologist 207, 505-518.

Milcu, A., Manning, P., 2011. All size classes of soil fauna and litter quality control the acceleration of litter decay in its home environment. Oikos 120, 1366-1370. 
Miller, P.C., Mangan, R., Kummerow, J., 1982. Vertical distribution of organic matter in eight vegetation types near Eagle Summit, Alaska. Ecography 5, 117-124.

Myers-Smith, I., Hik, D., Kennedy, C., Cooley, D., Johnstone, J., Kenney, A., Krebs, C., 2011a. Expansion of canopy-forming willows over the twentieth century on Herschel Island, Yukon Territory, Canada. AMBIO 40, 610-623.

Myers-Smith, I.H., Forbes, B.C., Wilmking, M., Hallinger, M., Lantz, T., Blok, D., Tape, K.D., Macias-Fauria, M., Sass-Klaassen, U., Lévesque, E., Boudreau, S., Ropars, P., Hermanutz, L., Trant, A., Collier, L.S., Weijers, S., Rozema, J., Rayback, S.A., Schmidt, N.M., Schaepman-Strub, G., Wipf, S., Rixen, C., Ménard, C.B., Venn, S., Goetz, S., Andreu-Hayles, L., Elmendorf, S., Ravolainen, V., Welker, J., Grogan, P., Epstein, H.E., Hik, D.S., 2011b. Shrub expansion in tundra ecosystems: dynamics, impacts and research priorities. Environmental Research Letters 6, 045509.

Nauta, A.L., Heijmans, M.M.P.D., Blok, D., Limpens, J., Elberling, B., Gallagher, A., Li, B.X., Petrov, R.E., Maximov, T.C., van Huissteden, J., Berendse, F., 2015. Permafrost collapse after shrub removal shifts tundra ecosystem to a methane source. Nature Climate Change 5, 67-70.

Novozamsky, I., Houba, V.J.G., van Eck, R., van Vark, W., 1983. A novel digestion technique for multi element plant analysis. Communications in Soil Science and Plant Analysis 14, 239-248.

Oechel, W.C., Hastings, S.J., Vourlrtis, G., Jenkins, M., Riechers, G., Grulke, N., 1993. Recent change of Arctic tundra ecosystems from a net carbon dioxide sink to a source. Nature 361, 520-523.

Poorter, H., Niklas, K.J., Reich, P.B., Oleksyn, J., Poot, P., Mommer, L., 2012. Biomass allocation to leaves, stems and roots: meta-analyses of interspecific variation and environmental control. New Phytologist 193, 30-50.

Robinson, C., Kirkham, J., Littlewood, R., 1999. Decomposition of root mixtures from high arctic plants: a microcosm study. Soil Biology and Biochemistry 31, 1101-1108.

Robinson, C.H., 2002. Controls on decomposition and soil nitrogen availability at high latitudes. Plant and Soil 242, 65-81.

Robinson, C.H., Michelsen, A., Lee, J., Whitehead, S., Callaghan, T.V., Press, M., Jonasson, S., 1997. Elevated atmospheric $\mathrm{CO}_{2}$ affects decomposition of Festuca vivipara (L.) Sm. litter and roots in experiments simulating environmental change in two contrasting arctic ecosystems. Global Change Biology 3, 37-49.

Scheffer, R.A., Aerts, R., 2000. Root decomposition and soil nutrient and carbon cycling in two temperate fen ecosystems. Oikos 91, 541-549.

Schuur, E.A.G., Vogel, J.G., Crummer, K.G., Lee, H., Sickman, J.O., Osterkamp, T.E., 2009. The effect of permafrost thaw on old carbon release and net carbon exchange from tundra. Nature 459, 556-559.

Shaver, G.R., Chapin, F.S., III, 1991. Production: biomass relationships and element cycling in contrasting arctic vegetation types. Ecological Monographs 61, 1-31.

Snyder, J.M., Rejmánková, E., 2015. Macrophyte root and rhizome decay: the impact of nutrient enrichment and the use of live versus dead tissue in decomposition studies. Biogeochemistry 124, 45-59.

Strickland, M.S., Lauber, C., Fierer, N., Bradford, M.A., 2009. Testing the functional significance of microbial community composition. Ecology 90, 441-451.

Sullivan, P., Sommerkorn, M., Rueth, H., Nadelhoffer, K., Shaver, G., Welker, J., 2007. Climate and species affect fine root production with long-term fertilization in acidic tussock tundra near Toolik Lake, Alaska. Oecologia 153, 643-652.

Swift, M.J., Heal, O.W., Anderson, J.M., 1979. Decomposition in Terrestrial Ecosystems. University of California Press, Berkeley and Los Angeles. 
Tape, K., Sturm, M., Racine, C., 2006. The evidence for shrub expansion in northern Alaska and the Pan Arctic. Global Change Biology 12, 686-702.

Tarnocai, C., Canadell, J., Schuur, E., Kuhry, P., Mazhitova, G., Zimov, S., 2009. Soil organic carbon pools in the northern circumpolar permafrost region. Global Biogeochemical Cycles 23, GB2023.

Thormann, M.N., Bayley, S.E., Currah, R.S., 2001. Comparison of decomposition of belowground and aboveground plant litters in peatlands of boreal Alberta, Canada. Canadian Journal of Botany 79, 9-22.

Veen, G.F., Freschet, G.T., Ordonez, A., Wardle, D.A., 2015a. Litter quality and environmental controls of home-field advantage effects on litter decomposition. Oikos 124, 187-195.

Veen, G.F., Sundqvist, M.K., Wardle, D.A., 2015b. Environmental factors and traits that drive plant litter decomposition do not determine home-field advantage effects. Functional Ecology 29, 981-991.

Verbyla, D., 2008. The greening and browning of Alaska based on 1982-2003 satellite data. Global Ecology and Biogeography 17, 547-555.

Wagenmakers, E.-J., Farrell, S., 2004. AIC model selection using Akaike weights. Psychonomic Bulletin \& Review 11, 192-196.

Walker, D.A., Raynolds, M.K., Daniëls, F.J., Einarsson, E., Elvebakk, A., Gould, W.A., Katenin, A.E., Kholod, S.S., Markon, C.J., Melnikov, E.S., 2005. The circumpolar Arctic vegetation map. Journal of Vegetation Science $16,267-282$.

Wallenstein, M.D., McMahon, S., Schimel, J., 2007. Bacterial and fungal community structure in Arctic tundra tussock and shrub soils. FEMS Microbiology Ecology 59, 428-435.

Wang, P., Heijmans, M.M.P.D., Mommer, L., van Ruijven, J., Maximov, T.C., Berendse, F., $2016 a$. Belowground plant biomass allocation in tundra ecosystems and its relationship with temperature. Environmental Research Letters 11, 055003.

Wang, P., Mommer, L., van Ruijven, J., Berendse, F., Maximov, T.C., Heijmans, M.M.P.D., 2016b. Seasonal changes and vertical distribution of root standing biomass of graminoids and shrubs at a Siberian tundra site. Plant and Soil 407, 55-65.

Ward, S.E., Orwin, K.H., Ostle, N.J., Briones, M.J.I., Thomson, B.C., Griffiths, R.I., Oakley, S., Quirk, H., Bardgett, R.D., 2015. Vegetation exerts a greater control on litter decomposition than climate warming in peatlands. Ecology 96, 113-123.

Webb, E.E., Schuur, E.A.G., Natali, S.M., Oken, K.L., Bracho, R., Krapek, J.P., Risk, D., Nickerson, N.R., 2016. Increased wintertime $\mathrm{CO}_{2}$ loss as a result of sustained tundra warming. Journal of Geophysical Research: Biogeosciences 121, 249-265.

Wieder, W.R., Bonan, G.B., Allison, S.D., 2013. Global soil carbon projections are improved by modelling microbial processes. Nature Climate Change 3, 909-912.

Wookey, P.A., Aerts, R., Bardgett, R.D., Baptist, F., Bråthen, K.A., Cornelissen, J.H.C., Gough, L., Hartley, I.P., Hopkins, D.W., Lavorel, S., Shaver, G.R., 2009. Ecosystem feedbacks and cascade processes: understanding their role in the responses of Arctic and alpine ecosystems to environmental change. Global Change Biology 15, 1153-1172.

Zhang, D., Hui, D., Luo, Y., Zhou, G., 2008. Rates of litter decomposition in terrestrial ecosystems: global patterns and controlling factors. Journal of Plant Ecology 1, 85-93.

Zimov, S.A., Schuur, E.A.G., Chapin, F.S., III, 2006. Permafrost and the global carbon budget. Science 312, 1612-1613. 
679

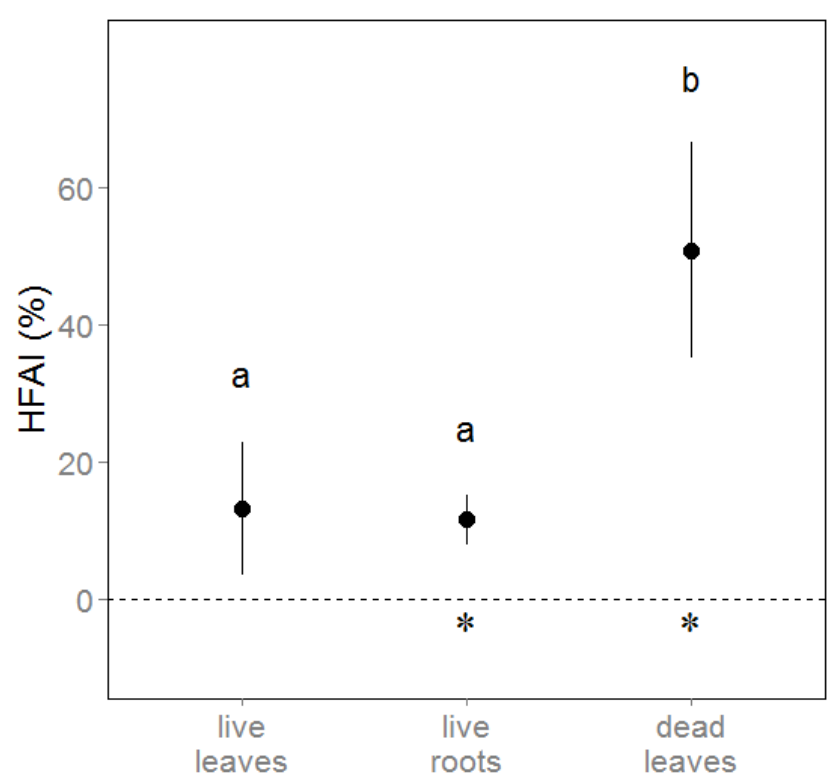

680

681 Fig. S1. Home-field advantage index (HFAI) of litter from different tissue types. Letters above error 682 bars indicate significant difference between groups. Asterisks show that HFAI was significantly

683 different from zero for live root and dead leaf litter. Dotted line represents zero level of HFAI.

684 Symbols with error bars show mean $\pm \mathrm{SE}, \mathrm{n}=8$ blocks.

685 
Table S1. Overview of the collection and preparation of samples used in this experiment

\begin{tabular}{|c|c|c|c|c|c|}
\hline & Litter type & $\begin{array}{l}\text { Time of } \\
\text { collection }\end{array}$ & Location of collection & $\begin{array}{l}\text { Drying } \\
\text { method }\end{array}$ & $\begin{array}{c}\text { Drying } \\
\text { time }\end{array}$ \\
\hline \multirow{4}{*}{$\begin{array}{c}\text { Live } \\
\text { materials }\end{array}$} & E. vaginatum live leaves & July 2013 & $\begin{array}{r}\text { E. vaginatum } \\
\text { dominated vegetation }\end{array}$ & $\begin{array}{r}65^{\circ} \mathrm{C} \text { ove } \\
\mathrm{n} \text { dried }\end{array}$ & $72 \mathrm{~h}$ \\
\hline & B. nana live leaves & July 2013 & $\begin{array}{r}\text { B. nana dominated } \\
\text { vegetation }\end{array}$ & $\begin{array}{r}65^{\circ} \mathrm{C} \\
\text { oven dried }\end{array}$ & $72 \mathrm{~h}$ \\
\hline & B. nana live roots & July 2013 & $\begin{array}{r}\text { B. nana dominated } \\
\text { vegetation }\end{array}$ & $\begin{array}{r}65^{\circ} \mathrm{C} \\
\text { oven dried }\end{array}$ & $72 \mathrm{~h}$ \\
\hline & E. vaginatum live roots & July 2015 & $\begin{array}{l}\text { Nearby E. vaginatum } \\
\text { dominated vegetation }\end{array}$ & $\begin{array}{r}\sim 10^{\circ} \mathrm{C} \\
\text { air dried }\end{array}$ & $24 \mathrm{~h}$ \\
\hline \multirow{3}{*}{$\begin{array}{c}\text { Dead } \\
\text { materials }\end{array}$} & $\begin{array}{l}\text { E. vaginatum dead } \\
\text { leaves }\end{array}$ & July 2015 & $\begin{array}{l}\text { Nearby E. vaginatum } \\
\text { dominated vegetation }\end{array}$ & $\begin{array}{r}\sim 10^{\circ} \mathrm{C} \\
\text { air dried }\end{array}$ & $24 \mathrm{~h}$ \\
\hline & E. vaginatum dead roots & July 2015 & $\begin{array}{l}\text { Nearby } E . \text { vaginatum } \\
\text { dominated vegetation }\end{array}$ & $\begin{array}{r}\sim 10^{\circ} \mathrm{C} \\
\text { air dried }\end{array}$ & $24 \mathrm{~h}$ \\
\hline & B. nana dead leaves & July 2015 & $\begin{array}{r}\text { Nearby } B . \text { nana } \\
\text { dominated vegetation }\end{array}$ & $\begin{array}{r}\sim 10^{\circ} \mathrm{C} \\
\text { air dried }\end{array}$ & $24 \mathrm{~h}$ \\
\hline
\end{tabular}

689 Table S2. Comparison of the regression models of mass loss and chemical characteristics using AIC 690 values and Akaike weights.

\begin{tabular}{lcrrc}
\hline Model parameter & $\begin{array}{c}\text { Log- } \\
\text { likelihood }\end{array}$ & AIC & $\Delta$ AIC & $\begin{array}{c}\text { Akaike } \\
\text { weight }\end{array}$ \\
\hline $\mathrm{N}$ & 6.95 & -7.91 & 12.38 & 0.001 \\
$\mathrm{P}$ & 13.15 & -20.29 & 0.00 & 0.479 \\
Lignin & 6.26 & -6.52 & 13.77 & 0.001 \\
$\mathrm{C}: \mathrm{N}$ & 7.69 & -9.38 & 10.91 & 0.002 \\
$\mathrm{C}: \mathrm{P}$ (ln transformed) & 11.68 & -17.36 & 2.93 & 0.111 \\
Lignin:N (ln transformed) & 9.31 & -12.63 & 7.66 & 0.010 \\
Lignin:P (ln transformed) & 12.95 & -19.91 & 0.38 & 0.396 \\
\hline
\end{tabular}

